\title{
Molecular characterisation of UK isolates of barley yellow mosaic bymovirus
}

\author{
Nong-nong Shi ${ }^{a, 1}$, Muyuan Zhu ${ }^{b, 2}$, Jianping Chen ${ }^{a, 1}$, Rebecca Stratford ${ }^{b}$, \\ T. Michael A. Wilson ${ }^{a}$, John F. Antoniw ${ }^{c}$, Ian J. Foulds ${ }^{b}$, \\ Stuart A. MacFarlane a , Michael J. Adams ${ }^{c, *}$ \\ ${ }^{a}$ Department of Virology, Scottish Crop Research Institute, Invergowrie, Dundee DD2 5DA, UK \\ ${ }^{b}$ Plant Breeding International Cambridge Ltd., Maris Lane, Trumpington, Cambridge CB2 $2 L Q, U K$ \\ ' Plant Pathology Department, LACR-Rothamsted, Harpenden, Herts, AL5 2JQ, UK \\ Received 11 April 1995; revised and accepted 23 May 1995
}

\begin{abstract}
Several isolates of barley yellow mosaic virus (BaYMV) from different sites in the UK, including some that were virulent on European resistant winter barley cultivars (resistancebreaking strain: BaYMV-2) and some that were not, were examined by RT-PCR, restriction mapping and sequencing of selected parts of the virus genome. Nucleotide and predicted amino acid sequences were determined for the 5'-terminal region, part of the NIa coding region and the coat protein coding region on RNA 1 and an area at the $\mathrm{N}$-terminus of the $70-\mathrm{kDa}$ protein coding region on RNA 2 . The sequences differed from those previously reported for a BaYMV isolate from Japan and for two German isolates, one of which was of the BaYMV-2 strain. There were no strain-specific amino acid differences and the few, non-consecutive, nucleotide differences detected were probably not significant and were insufficient to develop a rapid diagnostic test to distinguish BaYMV-2 from other isolates. Restriction mapping of RNA 2 cDNA again showed no consistent strain-related differences. The differences previously reported between the two German isolates are probably not strain-related.
\end{abstract}

Keywords: Barley yellow mosaic virus; Resistance-breaking strain; Isolate difference

\footnotetext{
* Corresponding author. Tel. +44 (1582) 763133. Fax: + 44 (1582) 760981. E-mail: mike.adams@bbsrc.ac.uk.

${ }^{1}$ Permanent address: Virology Laboratory, Zhejiang Academy of Agricultural Sciences, Hangzhou, People's Republic of China.

${ }^{2}$ Permanent address: Hangzhou University, Hangzhou, People's Republic of China. 


\section{Introduction}

Barley yellow mosaic virus (BaYMV) is the type member of the bymovirus subgroup of the Potyviridae. It is one of two bymoviruses common on winter barley in north-western Europe and in East Asia and is transmitted by the plasmodiophoraceous fungus Polymyxa graminis Ledingham (Adams, 1990). Infection by mechanical inoculation is difficult and unreliable. The virus is controlled by growing cultivars resistant to the virus and, on the basis of cultivar response, a total of 6 different virus strains have been identified in Japan (Kashiwazaki et al., 1989). In Europe, resistant cultivars grown since the disease first appeared in the late 1970s have all possessed the same resistance gene, ym4, located on chromosome 3 (Graner and Bauer, 1993). Since 1988, a resistance-breaking strain, usually called BaYMV-2, has been reported from several European countries (Huth, 1989; Hariri et al., 1990; Adams, 1991). Attempts to distinguish the two European strains of BaYMV serologically have proved unsuccessful (M.J. Adams, unpublished; W. Huth, personal communication; H. Lapierre, personal communication).

BaYMV has a single-stranded, positive-sense RNA genome with two components of approximately 7.6 and $3.5 \mathrm{~kb}$. The nucleotide sequences of isolates from Japan (strain II-1, here designated BaYMV-J) and Germany (BaYMV-G) have been determined (Kashiwazaki et al., 1990, 1991; Davidson et al., 1991; Peerenboom et al., 1992) and were found to have homologies of 93.6\% (RNA 1) and $90.4 \%$ (RNA 2). Each RNA encodes a single polypeptide which is then processed into at least 5 (RNA 1) and 2 (RNA 2) products. The capsid protein is at the C-terminus of the RNA 1 polypeptide, while the RNA 2 products are a $28-\mathrm{kDa}$ protein with homologies to the helper component proteinase of potyviruses and a 70-kDa protein of unknown function (see Fig. 1). Subsequently a German isolate of BaYMV-2 (here designated BaYMV-G2) was cloned and compared by restriction mapping with the previously published data (Bendiek et al., 1993). There was a high level of restriction site conservation for RNA 1 and for the majority of RNA 2 but a region with several differences was detected at the $\mathrm{N}$-terminus of the $70-\mathrm{kDa}$ protein on RNA 2. The sequence of 621 nucleotides in this region was determined and, while most of the nucleotide differences were silent, a difference of 3 amino acids between BaYMV-G2 and BaYMV-G was predicted. The coat protein coding region on RNA 1 was also sequenced and two amino acid differences between BaYMV-G2 and BaYMV-G were predicted.

The aim of the present work was to characterise UK isolates of BaYMV, including some that were from the BaYMV-2 strain and some that were not, to determine whether the differences previously described (Bendiek et al., 1993) occurred consistently between UK strains and to assess the feasibility of developing a rapid diagnostic test based on these differences (e.g., RT-PCR) to distinguish the strains. We report here the characterisation of several UK isolates, including restriction, enzyme analysis of cDNA from RNA 2 and the sequences of RT-PCRderived clones from 3 regions of RNA 1 and one of RNA 2, showing that these isolates were extremely similar to each other and that no consistent differences in these regions correlated with the resistance-breaking characteristic. 


\section{Materials and methods}

\subsection{BaYMV isolates and RNA isolation}

Barley leaves with typical symptoms were collected from various field sites (Table 1) and stored at $-70^{\circ} \mathrm{C}$. For some experiments, virus was purified as described by Huth et al. (1984) but with the addition of $1 \mathrm{mM}$ phenyl methyl sulphonyl fluoride as a protease inhibitor. RNA was then isolated from the purified virus by incubation with $0.1 \mathrm{mg} / \mathrm{ml}$ proteinase $\mathrm{K}$ in $0.1 \%$ SDS for $20 \mathrm{~min}$ at room temperature, followed by extraction with an equal volume of phenol-chloroform and ethanol precipitation. For other experiments, total plant RNA was obtained by maceration of $0.2 \mathrm{~g}$ frozen leaf with $2 \mathrm{ml}$ TLES buffer (100 mM Tris- $\mathrm{HCl}, \mathrm{pH} 8.0,100 \mathrm{mM} \mathrm{LiCl}, 10 \mathrm{mM}$ EDTA, $1 \%$ SDS) and extraction with an equal volume of phenol-chloroform. The aqueous phase was mixed with an equal volume of $4 \mathrm{M} \mathrm{LiCl}$ and precipitated on ice overnight. After centrifugation, pellets were washed with $70 \%$ ethanol, air dried, resuspended in distilled water and stored at $-70^{\circ} \mathrm{C}$.

\section{2. $R T-P C R$}

First-strand cDNA was synthesised and PCR used to amplify genome fragments from 3 separate parts of RNA 1 and almost all of RNA 2 (nt 31-3585) as shown in Fig. 1, using the oligonucleotide primers specified in Table 2. The RNA 1 fragments $(\mathrm{A}-\mathrm{C})$ were each of approximately $0.9 \mathrm{~kb}$ and consisted of the coat
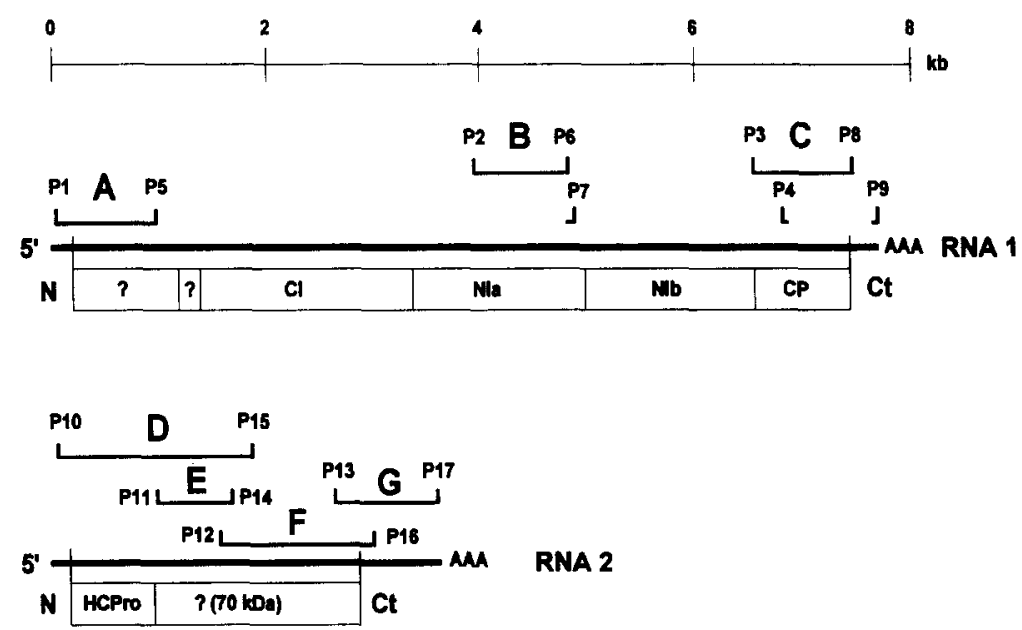

Fig. 1. Map of BaYMV genome and putative protein products showing the genome fragments (A-G) amplified and/or sequenced and the positions of primers (P1-P17) detailed in Table 2. CP, coat protein. Other proteins with functions tentatively assigned from homologies with potyviruses are: $\mathrm{CI}$, cytoplasmic inclusion; NIa, nuclear inclusion (proteinase); NIb, nuclear inclusion (polymerase); HCPro, helper component proteinase. 
Table 1

Sources of barley yellow mosaic virus isolates used in this study

\begin{tabular}{|c|c|c|c|}
\hline Isolate & Location & Cultivar & Comments \\
\hline \multicolumn{4}{|c|}{ Common strain } \\
\hline $1-1$ & $\begin{array}{l}\text { Hadleigh, Southend, } \\
\text { Essex }\end{array}$ & Panda & $\begin{array}{l}\text { Presumed common strain as no ym4 } \\
\text { cultivars had been grown }\end{array}$ \\
\hline $1-2$ & Eastleach, Glos & $\begin{array}{l}\text { Mixed } \\
\text { susceptible }\end{array}$ & $\begin{array}{l}y m 4 \text { cultivars growing at the same time } \\
\text { on this site were not infected }\end{array}$ \\
\hline \multicolumn{4}{|c|}{$B a Y M V-2$} \\
\hline $2-1$ & Steeple Claydon, Bucks & Mimosa & $y m 4$ cultivar \\
\hline $2-2$ & Eastleach, Glos & Torrent & ym4 cultivar \\
\hline $2-3$ & Hatherop, Glos & Target & $y m 4$ cultivar \\
\hline $2-4$ & Crawley, Oxon & Target & $y m 4$ cultivar \\
\hline
\end{tabular}

protein coding region $(\mathrm{C})$ and two others $\left(\mathrm{A}\right.$, the $5^{\prime}$-end; $\mathrm{B}$, part of the NIa coding region) chosen because they showed the greatest sequence diversity between the Japanese and German published sequences. Amplification of fragments A and B on RNA 1 were done with isolates 1-1, 1-2, 2-1 and 2-2; all other experiments used isolates 1-2, 2-3 and 2-4. First-strand cDNA synthesis used Superscript ${ }^{\mathrm{TM}}$ reverse transcriptase (Life Technologies Ltd.) according to the manufacturer's instructions

Table 2

Primers used for PCR and sequencing

\begin{tabular}{|c|c|c|}
\hline Primer & Position ${ }^{a}$ & Sequence \\
\hline \multicolumn{3}{|l|}{ RNA 1} \\
\hline $\mathrm{P} 1(+)$ & $32-55$ & $5^{\prime}$-CAA AAC GAA ACA AAC ACA AAC ATC- $3^{\prime}$ \\
\hline$P 2(+)^{b}$ & $3885-3907$ & $5^{\prime}$-[GCG ATC GAT] ACA GAT AGC AAG ATT CTG GAA GC-3' \\
\hline $\mathrm{P} 3(+)$ & $6516-6532$ & 5'-CAA GCA GCT GAT CCT CT-3' \\
\hline $\mathrm{P} 4(+)$ & $6768-6784$ & $5^{\prime}$-GAT GGT AAC TGG AGC GT-3' \\
\hline P5 $(-)^{b}$ & $946-926$ & $5^{\prime}$-[GCG GAA TTC] TAT GTA AGA TAG GGA TAA CGC-3' \\
\hline P6 $(-)$ & $4785-4766$ & 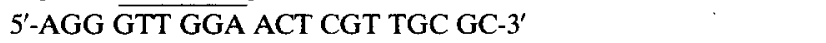 \\
\hline $\mathbf{P} 7(-)$ & $4828-4812$ & 5'-TTT GTT CCA GGT CCA TT-3' \\
\hline $\mathbf{P} 8(-)$ & $7415-7399$ & 5'-GGT TTA GGT TAG TTC TG-3' \\
\hline $\mathbf{P} 9(-)$ & $7643-7627$ & 5'-ATT ACC TTC TGG TAC TC-3' \\
\hline \multicolumn{3}{|l|}{$R N A 2$} \\
\hline P10 + + & $31-48$ & $5^{\prime}$-CAA AAC GAA ACA AAC ACA- $3^{\prime}$ \\
\hline P11(+) & $944-960$ & 5'-CAC AAA TTG GAA CTC TG-3' \\
\hline $\mathrm{P} 12(+)$ & $1521-1537$ & 5'-GAA CCA GTT GCT AGT GG-3' \\
\hline $\mathrm{P} 13(+)$ & $2610-2626$ & 5'-GAA GCA TCC AAT CTC AG-3' \\
\hline $\mathrm{P} 14(-)$ & $1648-1632$ & 5'-TGG AAT TTG ACA CGC TT-3' \\
\hline $\mathbf{P} 15(-)$ & $1854-1838$ & 5'-AGA CAA CCT CCC CAA AA-3' \\
\hline P16(-) & $2949-2933$ & $5^{\prime}$-ACC GCT AAC TCT ACC AT-3' \\
\hline $\mathbf{P} 17(-)$ & $3585-3569$ & 5'-GTC ACA TTT CCT GTG TA-3' \\
\hline
\end{tabular}

${ }^{a}$ Based on data from German isolates (Davidson et al., 1991; Peerenboom et al., 1992).

${ }^{b}$ Primers P2 and P5 have additional bases at their $5^{\prime}$-end (bracketed) containing ClaI (P2) or Eco RI (P5) sites (underlined). 
and primer P7 (fragments A and B), P9 (fragment C) or P17 (RNA 2 fragments). PCR reactions for fragments $A$ and $B$ contained $1 \mu$ l template cDNA, 20 pmol of each amplification primer, $200 \mu \mathrm{M}$ each dNTP, $1.2 \mathrm{U}$ Taq DNA polymerase (Promega), $1.5 \mathrm{mM} \mathrm{MgCl}, 50 \mathrm{mM} \mathrm{KCl}, 0.1 \%$ Triton X-100 and $10 \mathrm{mM}$ Tris- $\mathrm{HCl}$, $\mathrm{pH} 9.0$, in a $50 \mu \mathrm{l}$ volume. Amplifications were for 30 cycles each of $30 \mathrm{~s}$ at $94^{\circ} \mathrm{C}, 1$ min at $55^{\circ} \mathrm{C}$ and $2.5 \mathrm{~min}$ at $72^{\circ} \mathrm{C}$, followed by a 10 -min extension at $72^{\circ} \mathrm{C}$. PCR reactions for the remaining fragments were similar except that Tris- $\mathrm{HCl}$ was $\mathrm{pH}$ 8.3, Triton X-100 was omitted and 2.5 U Taq DNA polymerase (Life Technologies Ltd.) were added after denaturing the template DNA at $94^{\circ} \mathrm{C}$ for $3 \mathrm{~min}$. Amplifications were for 30 cycles, each of $1 \mathrm{~min}$ at $94^{\circ} \mathrm{C}, 1 \mathrm{~min}$ at $43^{\circ} \mathrm{C}$, and $72^{\circ} \mathrm{C}$ for $1-2$ min (estimated at $1 \mathrm{~min}$ synthesis time for each $1 \mathrm{~kb}$ of product). Successful amplification of fragments of the expected size was confirmed by $1 \%$ agarose gel electrophoresis.

\subsection{Cloning of the PCR products}

PCR fragments $A$ and $B$ were gel purified and blunt ended by incubating at $14^{\circ} \mathrm{C}$ for 10 min with $0.5-4.0 \mathrm{U}$ T4 DNA polymerase (Life Technologies Ltd.), 10 $\mu \mathrm{M}$ dNTPs, $50 \mathrm{mM}$ Tris- $\mathrm{HCl}, \mathrm{pH} 8.0,10 \mathrm{mM} \mathrm{MgCl}_{2}$ and $50 \mathrm{mM} \mathrm{NaCl}$. The reaction was extracted once with phenol-chloroform, ethanol precipitated and digested with either ClaI (A) or EcoRI (B) restriction enzymes (Life Technologies Ltd.). The reaction was stopped by extraction with phenol-chloroform, ethanol precipitated and then incubated for $30 \mathrm{~min}$ at $37^{\circ} \mathrm{C}$ with $10 \mathrm{U} \mathrm{T} 4$ polynucleotide kinase (Life Technologies Ltd.) in ligation buffer $(50 \mathrm{mM}$ Tris- $\mathrm{HCl}, \mathrm{pH} 7.6,10 \mathrm{mM}$ $\mathrm{MgCl}_{2}, 1 \mathrm{mM}$ ATP, $1 \mathrm{mM}$ DTT, 5\% PEG 8000). The kinase reaction was terminated by heating to $70^{\circ} \mathrm{C}$ for $10 \mathrm{~min}$ and the products ligated into either EcoRI-SmaI or Cla I-SmaI digested Bluescript plasmid (Stratagene). Ligations were transformed into Escherichia coli strain DH5 (Life Technologies Ltd.), following the manufacturer's instructions. Fragments C, D, F and G were cloned using the vectors pCR II (InVitrogen) or pT7Blue (Novagen), following the protocols supplied.

\subsection{Restriction mapping of RNA 2}

For restriction mapping, DNA fragments D, F and G of each of the isolates 1-2, 2-3 and 2-4 were digested with 48 restriction endonucleases with hexanucleotide recognition sites according to the conditions recommended by the commercial suppliers. Restriction digests were fractionated by agarose gel electrophoresis in 0.8-1.5\% agarose gels with a 1-kb DNA ladder (Life Technologies Ltd.), routinely used as a size marker. The restriction maps for BaYMV-G, BaYMV-J and BaYMV-G2 were deduced from the published sequence data (Davidson et al., 1991; Kashiwazaki et al., 1991; Bendiek et al., 1993). When the restriction sites on the UK isolates were found to be different from each other or from any of the published data, more clones covering these regions were tested to confirm the differences. 


\subsection{Sequencing}

The Sequenase version 2.0 DNA sequencing kit (USB) was used as recommended by the supplier. For fragments $A$ and B, the ends of clones were sequenced using T7, T3, SK and KS primers and custom primers were synthesised to internal BaYMV sequences to complete the sequence. Fragment $\mathrm{C}$ (the coat protein coding region) was sequenced using a universal 17-mer primer (U-40, USB, complementary to the sequence of the vector downstream of the insert), the $\mathrm{T} 7$ promoter primer 5'-AATACGACTCACTATAG-3' (matching the vector sequence upstream of the insert) and primer P4 (Table 2). For the region previously suggested to show some variation (Bendiek et al., 1993), 3 clones of fragment D of each isolate were prepared and the required region ( $\mathrm{E}$, Fig. 1) sequenced using the primers P11 and P14 (Table 2).

\section{Results and discussion}

\section{1. $5^{\prime}$ and NIa fragments ( $A$ and $B$ ) from $R N A 1$}

In the first experiments, using only isolates 1-1 and 2-1, cloned PCR products were sequenced from at least two independent PCR reactions. Three regions of fragment $A$ and 3 regions of fragment $B$ were identified in which the isolates differed by two or more nucleotides. Oligonucleotide PCR primers were designed and successfully used in experiments to amplify isolate-specific fragments (results not shown). However, when these experiments were repeated with isolates 1-2 and $2-2$, strain-specific bands were not obtained. cDNA clones of the latter isolates were then sequenced and the nucleotide and predicted amino acid sequences of all isolates compared. There was $>95 \%$ nucleotide identity between the UK isolates and between them and BaYMV-G (Table 3). No differences were consistently strain-specific. Predicted amino acid differences between the European isolates, none of which was strain-specific, are shown in Table 4.

Table 3

Homologies between RNA sequences of isolates: 5'-end (upper right part of table) and NIa region (lower left part of table) of RNA 1

\begin{tabular}{lcccccc}
\hline Isolate & \multicolumn{5}{l}{ \% identity with isolates: } \\
\cline { 2 - 6 } & $1-1$ & $1-2$ & $2-1$ & $2-2$ & $\mathrm{G}$ & $\mathrm{J}$ \\
\hline $1-1$ & - & 96.3 & 97.9 & 96.9 & 96.9 & 92.6 \\
$1-2$ & 96.0 & - & 96.1 & 98.6 & 98.4 & 91.8 \\
$2-1$ & 97.1 & 96.9 & - & 96.3 & 96.3 & 92.3 \\
$2-2$ & 95.8 & 97.9 & 96.6 & - & 99.3 & 92.6 \\
G & 95.3 & 97.7 & 96.0 & 97.9 & - & 92.4 \\
J & 90.6 & 90.4 & 91.0 & 90.2 & 90.8 & - \\
\hline
\end{tabular}


Table 4

Amino acid differences amongst European BaYMV isolates in the $5^{\prime}$-end (polyprotein amino acids 1-257) and NIa region (amino acids 1255-1554) of RNA 1

\begin{tabular}{|c|c|c|c|c|c|c|c|c|c|c|c|c|c|}
\hline \multirow{2}{*}{$\begin{array}{l}\text { BaYMV } \\
\text { isolate }\end{array}$} & \multicolumn{13}{|c|}{ Amino acid position ${ }^{a}$} \\
\hline & 14 & 22 & 25 & 124 & 175 & 221 & 222 & 236 & 1258 & 1280 & 1312 & 1315 & 1316 \\
\hline$\overline{1-1}$ & $\mathbf{K}$ & $\mathbf{E}$ & $\overline{\mathrm{H}}$ & $F$ & $\mathbf{S}$ & $F$ & $\mathbf{L}$ & $E$ & $\mathrm{~K}$ & $\bar{K}$ & $\mathbf{E}$ & $\bar{I}$ & $\mathrm{~K}$ \\
\hline $1-2$ & $\mathbf{K}$ & $G$ & $\mathbf{P}$ & $\mathbf{L}$ & $S$ & $\mathrm{C}$ & L & $E$ & $\mathbf{K}$ & $\mathbf{K}$ & $\mathbf{H}$ & V & $\mathbf{K}$ \\
\hline $2-1$ & $\mathrm{Q}$ & $\mathrm{E}$ & $\mathbf{H}$ & $\mathbf{F}$ & $S$ & $\mathbf{F}$ & $\mathbf{L}$ & $E$ & $\mathrm{~K}$ & $\mathbf{K}$ & A & I & $\mathbf{R}$ \\
\hline $2-2$ & $\mathbf{K}$ & $\mathrm{E}$ & $\mathbf{P}$ & $\mathbf{F}$ & $\mathrm{T}$ & $\mathbf{F}$ & L & $\mathrm{E}$ & $\mathbf{K}$ & $\mathbf{R}$ & $\mathbf{N}$ & I & $\mathbf{K}$ \\
\hline G & $\mathbf{K}$ & $E$ & $\mathbf{P}$ & $F$ & $\mathbf{S}$ & $\mathbf{F}$ & C & $\mathbf{K}$ & $\mathbf{N}$ & $\mathbf{R}$ & $\mathbf{N}$ & I & $\mathbf{K}$ \\
\hline \multirow[t]{3}{*}{$\mathrm{J}^{\mathrm{b}}$} & $\mathbf{K}$ & $\mathbf{E}$ & $\mathbf{H}$ & $\mathbf{F}$ & G & $\mathbf{F}$ & L & A & $\mathbf{N}$ & $\mathbf{K}$ & $\mathbf{K}$ & I & $\mathbf{K}$ \\
\hline & \multicolumn{13}{|c|}{ Amino acid position ${ }^{a}$} \\
\hline & 1324 & 1326 & 1334 & 1341 & 1359 & 1361 & 1373 & 1378 & 1379 & 1380 & 1464 & 1466 & 1522 \\
\hline$\overline{1-1}$ & $\mathbf{K}$ & $S$ & $\mathrm{~S}$ & G & I & G & $\mathrm{T}$ & $T$ & $\mathbf{L}$ & $\mathrm{E}$ & $\mathbf{S}$ & I & $\mathbf{G}$ \\
\hline $1-2$ & $\mathbf{K}$ & $E$ & F & $G$ & I & $\mathrm{G}$ & $\mathbf{A}$ & $\mathrm{T}$ & $\mathbf{L}$ & $\mathbf{E}$ & $\mathbf{P}$ & I & $\mathbf{G}$ \\
\hline $2-1$ & $\mathbf{K}$ & $\mathrm{E}$ & $\mathbf{F}$ & G & I & A & $\mathrm{T}$ & $\mathbf{T}$ & $\mathbf{L}$ & $\mathrm{E}$ & $\mathbf{P}$ & A & G \\
\hline $2-2$ & $\mathbf{N}$ & $\mathrm{E}$ & $\mathbf{F}$ & A & $\mathrm{V}$ & V & $\mathbf{A}$ & $\mathbf{T}$ & $\mathbf{L}$ & $\mathbf{E}$ & $\mathbf{P}$ & I & A \\
\hline $\mathrm{G}$ & $\mathbf{K}$ & $\mathbf{E}$ & $F$ & G & V & G & $\mathrm{T}$ & $\mathbf{S}$ & $\mathbf{F}$ & G & $\mathbf{P}$ & I & $\mathbf{G}$ \\
\hline $\mathbf{J}^{\mathbf{b}}$ & $\mathbf{H}$ & D & $\mathbf{H}$ & $\mathbf{G}$ & $\mathbf{K}$ & A & $\mathbf{T}$ & $\mathrm{T}$ & $\mathbf{L}$ & $\mathrm{E}$ & $\mathbf{P}$ & I & $\mathrm{G}$ \\
\hline
\end{tabular}

\footnotetext{
Based on BaYMV-G sequence (Peerenboom et al., 1992).

bor comparison only. This isolate differed from all the European isolates in an additional $11\left(5^{\prime}\right.$ region) and 21 (NIa region) sites which are not shown.
}

\subsection{Coat protein region (C) from $R N A 1$}

Nucleic acid homologies were $>99 \%$ between the UK isolates (1-2, 2-3 and $2-4$ ) and $>96 \%$ between all isolates (Table 5). Examination of the predicted amino acid sequences showed that the very few (and non-consecutive) nucleotide differences amongst UK isolates were silent. Comparison of amino acid differences between all isolates (Table 6) showed that amino acid 56 of the UK isolates was identical to that of BaYMV-G2 and -J, while amino acid 64 of the UK isolates was identical to that of BaYMV-G and $-\mathrm{J}$. It therefore seems unlikely that the

Table 5

Homologies between RNA sequences of isolates: coat protein coding region of RNA 1 (upper right part of table) and $\mathrm{N}$-terminal region of the $70-\mathrm{kDa}$ protein on RNA 2 (lower left part of table)

\begin{tabular}{lcccccc}
\hline Isolate & \multicolumn{7}{l}{ \% identity with isolate: } & & \\
\cline { 2 - 6 } & $\mathbf{1 - 2}$ & $2-3$ & $2-4$ & G & G2 & J \\
\hline $1-2$ & - & 99.1 & 99.2 & 98.3 & 98.6 & 96.0 \\
$2-3$ & 98.9 & - & 99.9 & 99.2 & 99.3 & 96.2 \\
$2-4$ & 99.7 & 98.9 & - & 99.1 & 99.2 & 96.3 \\
G & 93.7 & 93.9 & 94.0 & - & 99.4 & 96.5 \\
G2 & 97.3 & 97.7 & 97.6 & 94.5 & - & 96.0 \\
J & 89.2 & 88.4 & 89.2 & 88.6 & 88.9 & - \\
\hline
\end{tabular}


Table 6

Amino acid differences amongst BaYMV isolates in the coat protein coding region

\begin{tabular}{llllllllllll}
\hline BaYMV & \multicolumn{7}{l}{ Amino acid position (from start of coat protein) } & & & & \\
isolate & I2 & I4 & I5 & 20 & 23 & 24 & 51 & 56 & 62 & 64 \\
\hline UK a & A & H & T & R & L & D & V & N & M & T \\
G & A & H & T & R & L & D & V & T & M & T \\
G2 & A & H & T & R & L & D & V & N & M & A \\
J & D & R & I & G & F & E & A & N & T & T \\
\hline
\end{tabular}

asolates 1-2, 2-3 and 2-4 were identical to each other.

difference at these sites between the two German isolates was related to resistance breaking.

\subsection{Restriction mapping of RNA 2}

RT-PCR amplifications of regions D, F and $G$ (see Fig. 1) from isolates 1-2, 2-3 and 2-4 gave specific fragments of the expected sizes. Attempts to amplify nearly full-length cDNA using primers P10 and P17, or the 2064-nt fragment at the 3'end using primers P12 and P17, were unsuccessful. Seventeen of the 48 restriction enzymes (Aat II, Acc I, Afl II, ApalI, BamHI, Bst EII, EcoO109I, Eco RI, EcoRV, KpnI, PacI, PpuMI, PvuI, SalI, SmaI, SnaBI and Tth111I) did not cut any of the UK isolates. Restriction maps using the (14) enzymes for which information in common was available (Fig. 2), demonstrated that the differences reported between the isolates of the two German strains did not occur between those from the UK. Using all 48 restriction enzymes, maps of the UK isolates 1-2 and 2-4 were identical and differed at 4 sites from isolate 2-3. UK isolates had about $70 \%$ of sites in common with BaYMV-G and about $60 \%$ with BaYMV-J (Table 7; Fig. 3 ).

\section{4. $N$-terminal part of 70-kDa coding region on $R N A 2(E)$}

Nucleotide sequences of 3 independent clones of each of isolates 1-2, 2-3 and 2-4 were determined. There was very close agreement between clones of the same isolate (two out of 3 were usually identical) and a consensus sequence was therefore constructed for comparisons between isolates. Homologies between UK isolates were $\geqslant 98.9 \%$ and they resembled BaYMV-G2 more than BaYMV-G (Table 5). Examination of the predicted amino acid sequences showed that the very few (and non-consecutive) nucleotide differences amongst UK isolates were silent, and that the sequence (representing amino acids 280-477 of the RNA 2 polyprotein) differed at 4 or 5 positions from one or other of the German sequences (Table 8). Of the 3 positions at which BaYMV-G differed from BaYMV-G2, the UK isolates resembled BaYMV-G at one and BaYMV-G2 at the other two. It is evident that there are no strain-specific differences within this region which might cause the biological differences or which might be used to develop a diagnostic test. 

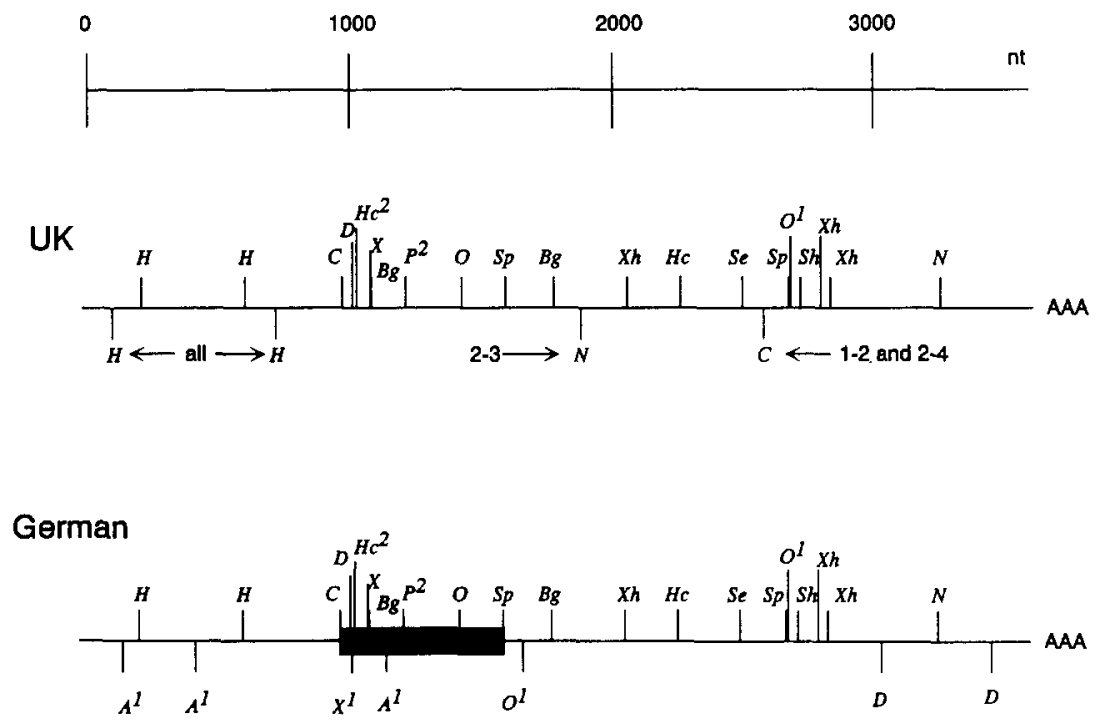

Fig. 2. Restriction maps of RNA 2 from three UK and two German isolates of BaYMV using 14 different restriction enzymes. Enzymes are: $A, A c c \mathrm{I} ; B g, B g \mathrm{III} C \mathrm{C}, \mathrm{Cla \textrm {I }} D \mathrm{D}, \mathrm{Dra \textrm {I }} \boldsymbol{H c}$, HincII; $H$, HindIII; $O, N c o$ I; N, NruI; P, Pst I; Se, SpeI; Sh, SphI;Sp,SspI; X,XbaI; Xh, XhoI. Sites in common between all UK and one or both of the German isolates are shown above the line. Sites shown below the line are unique to one or more of the isolates from that country. Superscripts 1 and 2 indicate that this site occurs on only one of the German isolates ( $G$ or G2 respectively) but on all UK isolates. Boxed area is the region previously sequenced (Bendiek et al., 1993) and also examined in this study.

Table 7

Summary of RNA 2 restriction site similarities amongst BaYMV isolates

\begin{tabular}{|c|c|c|c|c|c|c|}
\hline \multirow{2}{*}{$\begin{array}{l}\text { BaYMV } \\
\text { isolate }\end{array}$} & \multirow{2}{*}{$\begin{array}{l}\text { Total no. of } \\
\text { restriction } \\
\text { sites }\end{array}$} & \multicolumn{5}{|c|}{ No. of sites shared with isolate: } \\
\hline & & $\bar{J}$ & $\mathrm{G}$ & G2 & $1-2$ & $2-3$ \\
\hline \multicolumn{7}{|c|}{ (1) 48 enzymes } \\
\hline $\mathrm{J}$ & 52 & & & n.a. ${ }^{a}$ & & \\
\hline G & 55 & 30 & & n.a. & & \\
\hline UK $1-2$ & 56 & 33 & 40 & n.a. & & \\
\hline UK 2-3 & 55 & 34 & 40 & n.a. & 52 & \\
\hline UK 2-4 & 56 & 33 & 40 & n.a. & 56 & 52 \\
\hline \multicolumn{7}{|c|}{ (2) 14 enzymes } \\
\hline $\mathbf{J}$ & 21 & & & & & \\
\hline G & 25 & 13 & & & & \\
\hline G2 & 21 & 14 & 19 & & & \\
\hline UK 1-2 & 23 & 13 & 18 & 19 & & \\
\hline UK 2-3 & 23 & 14 & 18 & 19 & 22 & \\
\hline UK 2-4 & 23 & 13 & 18 & 19 & 23 & 22 \\
\hline
\end{tabular}

${ }^{\text {a }}$ n.a., data not available as Bendiek et al. (1993) ùsed fewer enzymes and complete nucleotide sequence of this isolate is not known. 

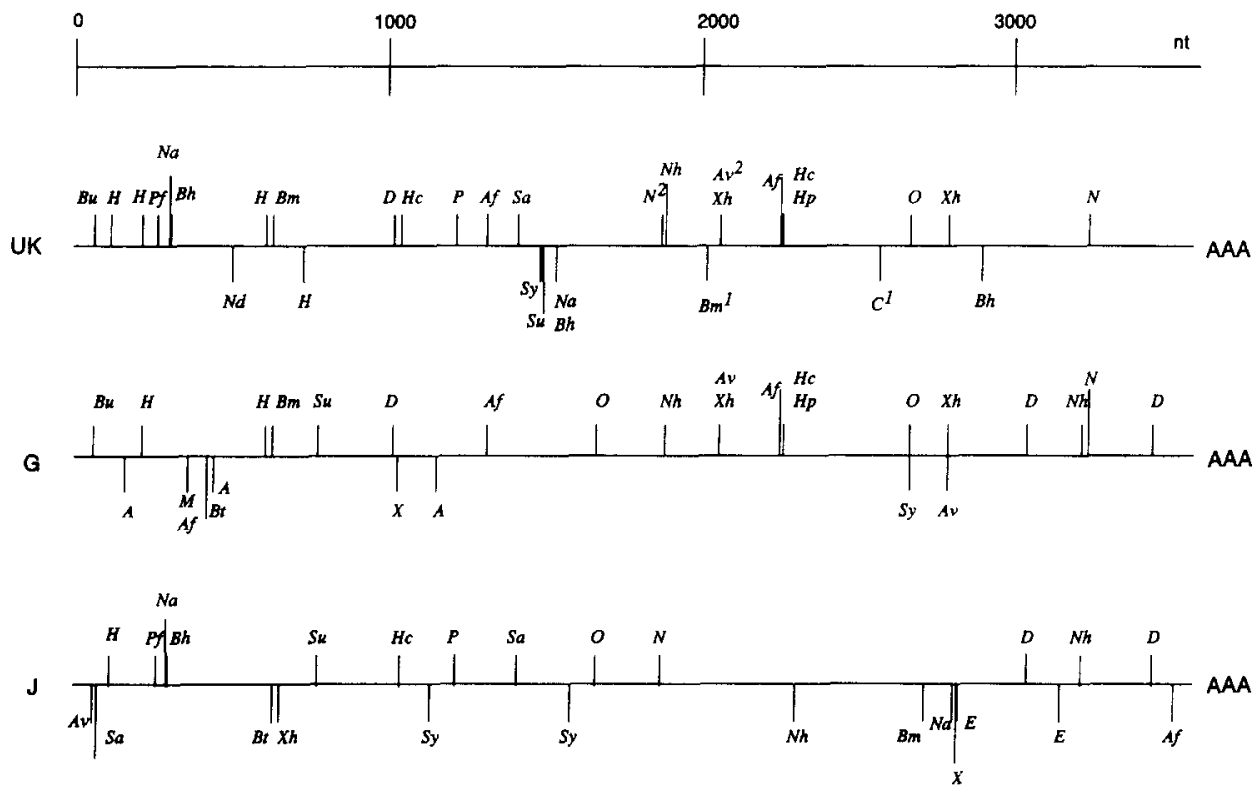

Fig. 3. Comparative restriction maps of RNA 2 of three UK isolates of BaYMV, BaYMV-G and BaYMV-J, using 48 different restriction enzymes. Enzymes additional to Fig. 2 are: $A f, A f l \mathrm{III} ; A v$, $A v a \mathrm{I} ; B h, B s a \mathrm{HI} ; B m, B s m \mathrm{I} ; B t, B s t \mathrm{BI} ; B u, B s u 36 \mathrm{I} ; E, E c o \mathrm{RI} ; H p, H p a \mathrm{I} ; M, M l u \mathrm{I} ; N a, N a r \mathrm{I} ; N d$, NdeI; Nh, Nhe I; Pf, Pfl MI; Sa, SacI; Su, StuI; Sy, StyI. Sites shown below the line are unique to that country. Superscript 1 indicates a site occurring only on isolates 1-2 and 2-4; superscript 2 indicates a site occurring only on isolate 2-3. Sites in common between all isolates are not mapped and were as follows: Afl III (295, 417); AvaI (2818); BglII (1085, 1775); BsaHI (315, 2812); Bsm I (275, 1385, 3382); Bst BI (1108); ClaI (982); MluI (417); MunI (3061); NcoI (1420); Sac I (1255); SpeI (2490); SphI (2707); Ssp I (1598, 2661); StyI (486, 1420, 1665); XbaI (1082); and XhoI (2818).

\subsection{Implications for strain differences and diagnosis}

Several regions of the genome were selected for study because of their known biological or diagnostic significance (e.g., the coat protein) or because they ap-

Table 8

Amino acid differences amongst European BaYMV isolates in the $\mathrm{N}$-terminal region of the 70-kDa protein (polyprotein amino acids 280-477) on RNA 2

\begin{tabular}{lllllll}
\hline BaYMV & \multicolumn{3}{l}{ Amino acid position } & & & \\
isolate & 280 & 305 & 358 & 436 & 446 & 471 \\
\hline UK $^{\text {a }}$ & $\mathrm{A}$ & $\mathrm{V}$ & $\mathrm{S}$ & $\mathrm{H}$ & $\mathrm{P}$ & I \\
G & $\mathrm{T}$ & $\mathrm{A}$ & $\mathrm{L}$ & $\mathrm{N}$ & $\mathrm{P}$ & $\mathrm{V}$ \\
G2 & $\mathrm{T}$ & $\mathrm{A}$ & $\mathrm{L}$ & $\mathrm{H}$ & $\mathrm{L}$ & $\mathrm{I}$ \\
$\mathrm{J}$ & $\mathrm{T}$ & $\mathrm{A}$ & $\mathrm{L}$ & $\mathrm{N}$ & $\mathrm{P}$ & $\mathrm{I}$ \\
\hline
\end{tabular}

${ }^{a}$ Isolates 1-2, 2-3 and 2-4 were identical to each other.

${ }^{b}$ For comparison only. This isolate differed from all the European isolates in an additional 14 sites which are not shown. 
peared to be regions where the genome was most variable. It was also decided to examine more than one isolate of each strain to increase the chance of finding differences that would be strain-specific. Despite this, the UK isolates proved to be very similar and no consistent strain-specific amino acid difference could be demonstrated. The few, non-consecutive nucleotide differences detected were probably not significant and were insufficient to develop a diagnostic test for BaYMV-2 isolates.

It is therefore highly probable that the restriction site, nucleotide and amino acid differences detected between BaYMV-G and BaYMV-G2 (Bendiek et al., 1993) are not related to resistance breaking. The absence of any consistent amino acid differences within the coat protein coding region explains the failure to develop strain-specific monoclonal antibodies. If a diagnostic test is to be developed, it seems that it will need to be nucleic-acid based. Analysis of other parts of the BaYMV genome will therefore be necessary.

\section{Acknowledgements}

We thank the UK farmers for permission to sample barley fields (Table 1) and Professor Chen Chuanqun, Director of the Zhejiang Academy of Agricultural Sciences for his support and interest. M.Z. gratefully acknowledges support from the Royal Society K.C. Wong Fellowship. The work was partly funded by a grant under the International Scientific Cooperation programme (CI1*-CT93-0081) of the Commission of the European Union and by the Ministry of Agriculture, Fisheries and Food and the Scottish Office Agriculture and Fisheries Department.

\section{References}

Adams, M.J. (1990) Host range and transmission of barley viruses by isolates of Polymyxa graminis. In: R. Koenig (Ed.), Proceedings of the First Symposium of the International Working Group on Plant Viruses with Fungal Vectors (Schriftenreihe der Deutschen Phytomedizinischen Gesellschaft 1). Ulmer, Stuttgart, pp. 121-123.

Adams, M.J. (1991) The distribution of barley yellow mosaic virus (BaYMV) and barley mild mosaic virus (BaMMV) in UK winter barley samples, 1987-1990. Plant Pathol. 40, 53-58.

Bendiek, J., Davidson, A., Schultze, S.C., Schell, J. and Steinbiss, H.-H. (1993) Identification and classification of a resistance breaking strain of barley yellow mosaic virus. Ann. Appl. Biol. 122, 481-491.

Davidson, A.D., Pröls, M., Schell, J. and Steinbiss, H.-H. (1991) The nucleotide sequence of RNA2 of barley yellow mosaic virus. J. Gen. Virol. 72, 989-993.

Graner, A. and Bauer, E. (1993) RFLP mapping of the ym4 resistance gene in barley. Theor. Appl. Genet. 86, 689-693.

Hariri, D., Fouchard, M. and Lapierre, H. (1990) Resistance to barley yellow mosaic virus and to barley mild mosaic virus in barley. In: R. Koenig (Ed.), Proceedings of the First Symposium of the International Working Group on Plant Viruses with Fungal Vectors (Schriftenreihe der Deutschen Phytomedizinischen Gesellschaft 1). Ulmer, Stuttgart, pp. 109-112.

Huth, W. (1989) Ein weiterer Stamm des Barley yellow mosaic virus (BaYMV) gefunden. Nachrichtenbl. Dtsch. Pflanzenschutzdienstes 41, 6-7. 
Huth, W., Lesemann, D.-E. and Paul, H.L. (1984) Barley yellow mosaic virus: purification, electron microscopy, serology and other properties of two types of the virus. Phytopathol. Z. 111, 37-54.

Kashiwazaki, S., Ogawa, K., Usugi, T., Omura, T. and Tsuchizaki, T. (1989) Characterization of several strains of barley yellow mosaic virus. Ann. Phytopathol. Soc. Jpn. 55, 16-25.

Kashiwazaki, S., Minobe, Y., Omura, T. and Hibino, H. (1990) Nucleotide sequence of barley yellow mosaic virus RNA1: a close evolutionary relationship with potyviruses. J. Gen. Virol. 71, 2781-2790.

Kashiwazaki, S., Minobe, Y. and Hibino, H. (1991) Nucleotide sequence of barley yellow mosaic virus RNA2. J. Gen. Virol. 72, 995-999.

Peerenboom, E., Pröls, M., Schell, J., Steinbiss, H.-H. and Davidson, A.D. (1992) The complete nucleotide sequence of RNA 1 of a German isolate of barley yellow mosaic virus and its comparison with a Japanese isolate. J. Gen. Virol. 73, 1303-1308. 